\title{
PEMANFAATAN CENDAWAN Beauveria bassiana(BALS.) VUILL. SEBAGAI MIKO-INSEKTISIDA TERHADAP KUTU LONCAT JERUK Diaphorina citri KUW. (HEMIPTERA: LIVIIDAE)
}

\section{Utilization Of Entomopathogenic Fungi Beauveria bassiana (Bals.) Vuill. As Myco-Insecticides Against Citrus Psyllid Diaphorina citri Kuw.(Hemiptera: Liviidae)}

\author{
Muhammad Agung Permadi ${ }^{1}$, Ruly Anwar ${ }^{2}$, Teguh Santoso ${ }^{2}$ \\ 1Fakultas Pertanian - Universitas Muhammadiyah Tapanui Selatan \\ Jl Raja Inal Siregar-Tanggal No 32, Padangsidimpuan 22716 \\ 2Departemen Proteksi Tanaman IPB \\ Jl Raya Dramaga, Bogor, Jawa Barat \\ *Corresponding author: E-mail: muhammad.agungp19@gmail.com
}

\begin{abstract}
Abstrak
Kutu loncat Diaphorina citri Kuwayama merupakan salah satu hama penting tanaman jeruk dan juga merupakan vektor dari penyakit serius yang dikenal dengan greening disease atau disebut Huanglongbing (HLB). Cendawan entomopatogen yang dapat digunakan untuk mengendalikan hama ini adalah Beauveria bassiana.Tujuan penelitian ini adalah mengukur kemampuan infeksi $B$. bassianaterhadap imago D. citri. Kerapatan konidia $B$. bassianayang digunakan adalah $10^{3}, 10^{4}, 10^{5}, 10^{6}$, $10^{7}$, dan $10^{8}$ konidia/ml, percobaan diulang sebanyak tiga kali. Penelitian ini menggunakan Rancangan Acak Lengkap (RAL).Nilai tengah diuji lanjut dengan menggunakan Uji Jarak Berganda Duncan (DMRT) pada taraf nyata $5 \%$.Hasil uji patogenisitas $B$. bassiana terhadap imagoD. citri berturut-turut menyebabkan mortalitas sebesar 10\%, 15\%, 18.33\%, 26.67\%, 33.33\% dan 53.33\%.Nilai LC $_{50} B$. bassianayang diperoleh sebesar $1.52 \times 10^{8}$ konidia/ml.
\end{abstract}

Kata Kunci : Entomopatogen, Infeksi, Kutu Loncat, Kepadatan Konidia, Mortalitas

\begin{abstract}
Asiatic citrus psyllid Diaphorina citri Kuwayama has been considered as one of important citrus pests and a vector of a serious citrus disease as well, greening disease or known as Huanglongbing (HLB). Among entomophatogenic fungi which can be used to control those pest insects isBeauveria bassiana.The objective of this study was to measure the infectivity ofB. bassianaagainst adult of $D$. citri.B. bassianaconidia that used were $10^{3}, 10^{4}, 10^{5}, 10^{6}, 10^{7}$, and $10^{8}$ conidia/ml.The experiment was repeated three times and arranged in a completely randomized design (CRD). Mean was analized by Duncan's multiple range test correction at the level $\alpha=0.05$. B. bassianacaused mortality of $D$. citriat rate of $10 \%$, 15\%, 18.33\%, 26.67\%, 33.33\% and 53.33\% respectively. The result showed that $L C_{50}$ of B. bassianawas $1.52 \times 10^{8}$ conidia $/ \mathrm{ml}$.
\end{abstract}

Keywords: Entomopathogenic, Infection, Psyllid, Conidial Density, Mortality

How to Cite: Permadi, M.A., Anwar, R., Santoso, T, 2017, Pemanfaatan Cendawan Beauveria bassiana (Bals.) Vuill. Sebagai Mikro-insektisida terhadap Kutu Loncat Jeruk Diaphoria citri Kuw. (Hamiptera:Liviidae), BioLink, Vol. 4 (1): Hal. 82-89 


\section{PENDAHULUAN}

Salah satu hama penting jeruk adalah kutu loncat jerukDiaphorina citri Kuwayama (Hemiptera: Liviidae). Kutu ini sangat merugikan karena merupakan vektor penyakit serius yaitu Huanglongbing (HLB) atau sering juga disebut citrus vein phloem degeneration (CVPD). HLBtelah menyebabkan hancurnya per-tanaman jeruk di Asia dan Afrika (Bove 2006).Penularan HLB sangat bergantung pada kepadatan populasi serangga vektor, pemencaran serangga vektor, dan sifat patogen dalam tubuh serangga. Pengendalian $D$. citriseba-gai vektor penyakit HLBpada umum-nya masih dilakukan secara kimiawi dengan menggunakan insektisida sin-tesis.

Penggunaan insektisida sintetis yang terus menerus dapat menim-bulkan resistensi hama, resurjensi, ledakan hama sekunder dan masalah residu racun pada lingkungan juga pada buah jeruk yang dikonsumsi.Usaha mengurangi pemakaian insek-tisida dalam pengendalian hama tanaman telah banyak dilakukan. Salah satunya denganpengendalian

hayatimelaluipenggunaan cendawan entomopatogen.Cendawan entomopatogen merupakan salah satu agens pengendalian hayati yang potensial untuk mengendalikan hama tanaman. Hal ini disebabkan keefektifan cendawan entomopatogen cukup tinggi terhadap hama target. Cenda-wan entomopatogen menginfeksi dengan menembus kutikula serangga inang, berbeda dengan bakteri dan virus yang harus termakan oleh serangga inang(Rai et al. 2014). Untuk serangga $D$. citriyang mempunyai tipe alat mulut menusuk dan menghisap, cendawan entomopatogen sangat sesuai untuk dipilih sebagai bioinsek-tisida.

Pengendalian dengan menggunakan cendawan entomopatogen tersebut mempunyai beberapa keuntungan antara lain: (1) relatif mudah diproduksi, (2) organisme yang digunakan sudah tersedia di alam, (3) mempunyai kapasitas reproduksi yang tinggi, (4) siklus hidupnya pendek, (5) sangat kecil kemungkinan terjadi resistensi (Prayogo \&Suharsono 2005). Salah satu cendawan entomopatogen yang sering digunakan untuk mengen-dalikan hama adalah Beauveria bassiana (Bals.) Vuill.Cendawan B. bassiana juga telah banyak dieks-plorasi kemampuannya dalam me-ngendalikan hama. Beberapa peneliti telah menguji keefektifan cendawan ini terhadap beberapa jenis hama diantaranya Ostrinia furnacalis (Lepi-doptera: Crambidae) (Agustin 2014), Cylas formicarius (Coleoptera: Bren-tidae) (Ahdiaty 2013), Frankliniella occidentalis (Thysanoptera: Thripi-dae) (Gao et al. 2012), Sitophilus zeamais (Coleoptera: Curculionidae) (Surtikanti et al. 2011), Spodoptera litura (Lepidoptera: Noctuidae) (Surtikanti \& Yasin 2009), Croci-dolomia pavonana (Lepidoptera: Crambidae) (Trizelia 2005) dan Leptinotarsa decemlineata (Coleo-ptera: Chrysomelidae) (Klinger 2003).

\section{METODE PENELITIAN}

Penelitian dilaksanakan di Laboratorium Patologi Serangga, Depar-temen Proteksi Tanaman, Fakultas Pertanian, Institut Pertanian Bogor, mulai bulan Februari 2015 sampai dengan Mei 2015. 
Permadi, M.A., Anwar, R., Santoso, T., Pemanfaatan Cendawan Beauveria bassiana (Bals.) Vuill. Sebagai

\section{Pemeliharaan D. citri}

Imago D. citri dikumpulkan dari perkebunan jeruk di Kampung Carang Pulang, Kelurahan Situ Gede, Kecamatan Bogor Barat, Kota Bogor. Imago yang telah didapatkan kemudian dimasukkan ke dalam ku-rungan serangga berukuran $100 \mathrm{~cm} \times 50 \mathrm{~cm}$ x $100 \mathrm{~cm}$ (pxlx t) yang telah berisi tanaman kemuning (Murraya pani-culata) sebagai tanaman inang.

\section{Perbanyakan B. bassiana pada Media Beras}

Dalam penelitian ini isolat $B$. bassiana yang digunakan berasal dari koleksi Laboratorium Patologi Se-rangga Departemen Proteksi Tana-man, Fakultas Pertanian, Institut Per-tanian Bogor.B. bassianaditum-buhkan pada media beras. Hal ini bertujuan untuk mendapatkan kera-patan konidia yang lebih tinggi. Beras yang sudah dicuci hingga bersih, dikukus setengah matang lalu didi-nginkan dalam nampan plastik. Media beras sebanyak $\pm 50 \mathrm{~g}$ dimasukkan ke dalam kantong-kantong plastik bening tahan panas HDPE (High Density Polyethylene), disterilisasi dalam au-toklaf (selama 35 menit dengan suhu 121. C dan tekanan $1 \mathrm{~atm})$. Media tersebut diinokulasi dengan B. bassianasetelah dingin. Inokulasi dila-kukan dengan menyemprotkan sus-pensi konidia cendawan ke dalam kantung beras. Semua tahapan dila-kukan pada kondisi steril dalam laminar air flow. Biakan cendawan ini diinkubasi selama 21 hari yang merupakan umur optimum untuk pengujian (Goettel \& Inglis 1997).
Aplikasi B. bassiana pada Imago $D$. citri

Kerapatan konidia cendawan $B$. bassiana dihitung menggunakan hemocytometer Neubauer-improved. Suspensi cendawan yang sudah dihi-tung kerapatan konidianya kemudian diaplikasikan pada imago D. citri. Kerapatan konidia yang digunakan adalah $10^{3}, 10^{4}, 10^{5}, 10^{6}, 10^{7}$, dan $10^{8}$ konidia/ml. Aplikasi dilakukan de-ngan cara menyemprotkan $0.5 \mathrm{ml}$ sus-pensi konidia pada imago D. citri.Serangga uji dimasukkan ke dalam wadah plastik berukuran $20 \mathrm{~cm}$ x $15 \mathrm{~cm}$ x $5 \mathrm{~cm}$ (p x l x t) yang telah dialasi tisu dan ditutup menggunakan kain kasa. Sebagai kontrol, serangga uji disemprot dengan akuades yang telah dicampur tween dengan volume yang sama. Imago kemudian ditempatkan pada tabung kaca berukuran tinggi $22.5 \mathrm{~cm}$ dengan diameter $2.5 \mathrm{~cm}$. Tabung kaca tersebut berisi daun kemuning yang pada bagian tang-kainya dibalut spons yang dibasahkan untuk menjaga kelembaban dan mencegah kehilangan air. Daun tersebut digunakan sebagai sumber serangga percobaan. Setiap satuan percobaan masing-masing terdiri dari 20 individu serangga ujidan diulang sebanyak 3 kali. Peubah yang diamati adalah jumlah imago yang mati akibat terinfeksi $B$. bassiana yang dihitung mulai waktu aplikasi sampai dengan 7 hari setelah aplikasi (HSA).

Persentase mortalitas imago dihitung menggunakan rumus:

$$
M=x 100 \%
$$


Keterangan:

$\mathrm{M}=$ Persentase mortalitas (\%)

$\mathrm{A}=$ Jumlah serangga yang mati akibat infeksi cendawan

$\mathrm{D}=$ Jumlah serangga yang diuji

\section{Rancangan Percobaan}

Penelitian ini menggunakan rancangan acak lengkap (RAL). Nilai tengah diuji dengan pengujian jarakberganda duncan (DMRT) dengan taraf nyata 5\%.

\section{HASIL DAN PEMBAHASAN}

Pada pengamatan pertama hari setelah aplikasi (HSA), belum ada D. citri yang mengalami kematian. D. citrimulai mengalami kematian sejak 2 HSAdisebabkan infeksi $B$. bassiana. Mortalitas D. citri terus bertambah hingga 7 HSA. Laju mortalitas kumulatif terendah D. citri sebesar $10 \%$ pada kerapatan konidia terendah yaitu $10^{3}$ konidia/ml, sedangkan laju kumulatif mortalitas tertinggi sebesar $53.33 \%$ pada kerapatan konidia tertinggi yaitu $10^{8}$ konidia/ml.Hasil analisis ragam dan uji lanjut DMRT dengan taraf nyata5\% menunjukkan hasil yang berbeda nyata (Tabel 1). Semakin tinggi kerapatan konidia/ml yang digunakan maka semakin tinggi mortalitas yang disebabkan.

Tabel 1. Mortalitas imago D. citri setelah 7 hari aplikasi B. bassiana

\begin{tabular}{ccc}
\hline Kerapatan (konidia/mL) & \multicolumn{2}{c}{ Mortalitas (\%) } \\
\hline Kontrol & 0 & $\mathrm{c}$ \\
$10^{3}$ & 10.00 & $\mathrm{bc}$ \\
$10^{4}$ & 15.00 & $\mathrm{bc}$ \\
$10^{5}$ & 18.33 & $\mathrm{bc}$ \\
$10^{6}$ & 26.67 & $\mathrm{bc}$ \\
$10^{7}$ & 33.33 & $\mathrm{ab}$ \\
$10^{8}$ & 53.33 & $\mathrm{a}$ \\
\hline
\end{tabular}

Keterangan: Angka yang diikuti huruf yang berbeda diartikan memiliki perbedaan yang nyata antara perlakuan yang satu dengan perlakuan yang lain pada taraf uji 0.05 menurut uji Duncan

Lethal concentration (LC) adalah nilai yang menunjukkan jumlah racun per satuan berat yang dapat mematikan populasi hewan yang digunakan dalam percobaan (Prijono 1985). Dalam pengujian imago $D$. citri diperoleh hasil LC $_{50}$ sebesar 1.52 x $10^{8}$ konidia/ml dengan persamaan regresi $\mathrm{y}=7.99 \mathrm{x}$ 1.88 yang menunjukkan hubungan antara kerapatan dan probit persentase mortalitas imago. 


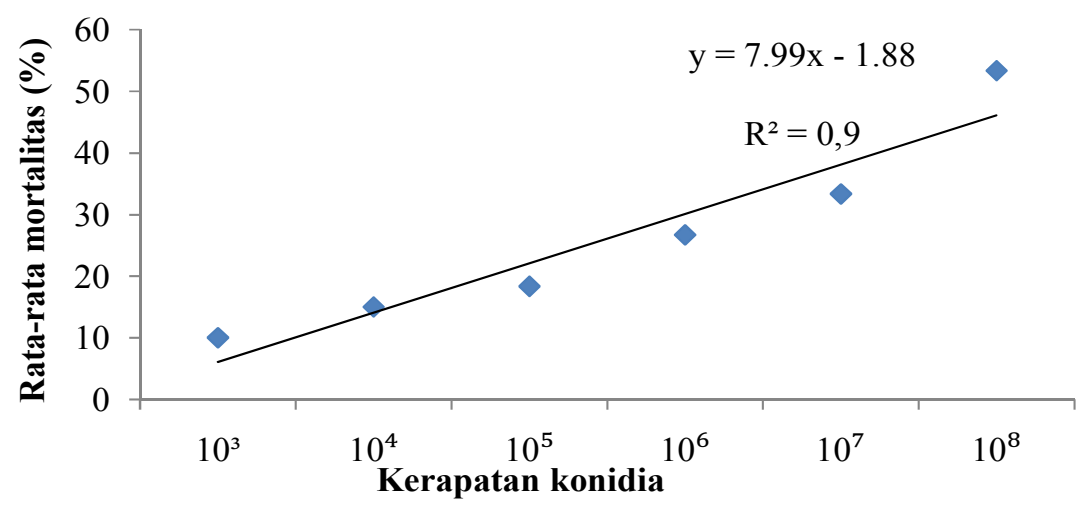

Gambar 1. Probit mortalitas (lethal concentration) B. bassiana terhadap mortalitas imago $D$. citri pada 7 hari setelah aplikasi

Tabel 2. Analisis probit B. bassianaterhadap mortalitas imago D. citripada 7 hari setelah aplikasi

\begin{tabular}{|c|c|c|c|c|}
\hline \multirow{2}{*}{$\begin{array}{c}\text { Kerapatan } \\
\text { (konidia/mL) }\end{array}$} & \multirow{2}{*}{$\begin{array}{c}\text { LC }_{50} \\
\text { (konidia/mL) }\end{array}$} & \multicolumn{2}{|c|}{ Fiducial limits } & \multirow{2}{*}{$\begin{array}{c}\text { Persamaan } \\
\text { regresi }\end{array}$} \\
\hline & & Lower & Upper & \\
\hline $10^{8}$ & $1.52 \times 10^{8}$ & $2.61 \times 10^{7}$ & $3.47 \times 10^{9}$ & $Y=7.99 x-1.88$ \\
\hline
\end{tabular}

Tubuh imago D. citri yang telah mati terinfeksi B. bassiana pada awalnya belum terlihat diselimuti miselia cendawan B. bassiana. Namun setelah diinkubasi dalam moist chamberselama 3 hari mulai terlihatbangkai D.citridiselimuti miselia berwarna putih seperti pada Gambar 2B.

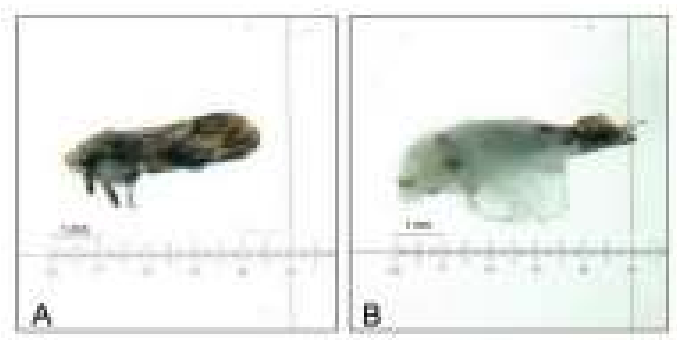

Gambar 2. Imago D. citri yang normal (A) dan yang terinfeksi $B$. bassiana (B)
Mortalitas imago D. citri akibat infeksi $B$. bassiana sudah mulai terjadi pada hari kedua. Hal ini sesuai dengan pernyataan Steinhaus (1999) bahwa $B$. bassianamampu berkecambah pada 2448 jam setelah kontak bila kondisi lingkungan lembab. Kematian serang-ga akibat cendawan biasanya terjadi 2 hari sampai 14 hari setelah terinfeksi, namun kematian bisa pula terjadi kurang dari 24 jam.Kematian imago D. citri yang disebabkan oleh infeksi cendawan membutuhkan waktu kare-na cendawan membutuhkan beberapa tahap proses untuk sampai meng-infeksi dan mematikan serangga.Besheli et al. (2006) menyatakan cen-dawan entomopatogen harus cocok dengan inangnya dan 
menghasilkan kombinasi enzim yang baik untuk dapat melakukan penetrasi tergantung kepada beberapa faktor patogenisitas, diantaranya faktor kesesuaian inang dan sifat fisiologis cendawan.

Mortalitas imago D. citri tertinggi disebabkan infeksi $B$. bassiana yaitu sebesar $53.33 \%$ pada kerapatan $10^{8}$ konidia/ml. Hal ini sejalan dengan penelitian Pacheco et al. (2013), B. bassiana dapat menyebabkan mor-talitas pada D. citri sebesar $60.66 \%$ pada kerapatan $10^{8}$ konidia/ml. Per-sentase mortalitas lebih rendah ditun-jukkan hasil penelitian Dwiastuti et al. (2007) bahwa $B$. bassiana hanya dapat menyebabkan mortalitas pada D. citri sebesar $31.99 \%$ pada kerapatan $10^{8}$ konidia/ml. Mortalitas serangga sa-ngat ditentukan oleh kerapatan konidia cendawan yang digunakan. Kerapatan konidia yang optimal untuk mengendalikan hama bergantung pada sumber isolat cendawan dan jenis serangga hama yang akan dikendalikan.Ke-mampuan cendawan $B$. bassiana dalam mematikan serangga hama bervariasi dan sangat dipengaruhi oleh karakter fisiologi dan genetik B. bassiana.

Berbeda halnya dengan bakteri dan virus yang harus termakan oleh serangga agar efektif, cendawan bia-sanya menginfeksi serangga melalui kutikula. Ferron (1985) menggo-longkan empat tahapan etiologi penya-kit serangga yang disebabkan olehcendawan. Tahap pertama adalah ino-kulasi, tahap kedua adalah proses penempelan dan perkecambahan pro-pagul cendawan pada integumen se-rangga, tahap ketiga yaitu penetrasi dan invasi, dan tahap keempat yaitu destruksi.

Cendawan entomopatogen biasanya menyebabkan kematian pada serangga inang dengan satu atau beberapa cara seperti toksinasi, defisiensi nutrisi, dan merusak jaringan. Kematian serangga biasanya terjadi karena toksinasi yang disebabkan cendawan, selanjutnya rusaknya jaringan tubuh serangga karena dipenuhi miselia yang menyebar dengan cepat dan meme-nuhi hemosel serangga inang, semua cairan inang digunakan untuk multi-pikasi cendawan sehingga menye-babkan serangga inang mati dengan tubuh mengeras (Trizelia 2005). Toksin yang dihasilkan cendawan menyebabkan kenaikan $\mathrm{pH}$ hemo-limfa, penggumpalan dan terhentinya peredaran hemolimfa serangga inang. Menurut penelitian Vey et al. (2001) toksin juga dapat menimbulkan gangguan pada fungsi hemolimfa dan nukleus serangga, sehingga mengakibatkan pembengkakan dan pengerasan pada serangga yang terinfeksi. Beberapa toksin yang dihasilkan oleh $B$. bassiana adalah bassianin, beau-vericin, bassianolide, beaverolides dan tenellin (Tanada \& Kaya 1993).

Hasil $\mathrm{LC}_{50}$ yang diperoleh dari pengujian $B$. bassiana terhadap imago $D$. $\begin{array}{llll}\text { citri sebesar } & 1.52 & \text { x } & 10^{8}\end{array}$ konidia/ml.Semakin kecil nilai $\mathrm{LC}_{50}$ yang dida-patkan menunjukkan semakin tinggi patogenisitas cendawan yang diuji.Persamaan regresi mortalitas $D$. citri akibat infeksi $B$. bassiana adalahy = $7.99 x-1.88$ dengan $R^{2}=0,91$. Semakin besar nilai $\mathrm{R}^{2}$, maka tanggap populasi terhadap perlakuan semakin homogen. Setiap individu memiliki kepekaan yang 
relatif sama jika popu-lasi homogen (Himawati 2003). Persa-maan regresi berguna untuk mem-perkirakan persentase mortalitas (y) yang didapatkan pada hari tertentu (x). Hasil dari persamaan didapatkan dengan memasukkan nilai $\mathrm{x}$ (hari ke-) pada persamaan regresi. Jika nilai $y$ (persentase mortalitas) bernilai minus maka dianggap nol, karena belum ada kematian dan kematian tidak benilai minus.Nilai kemiringan (slope) yang terbentuk sebesar 7.99. Nilai slope yang positif menunjukkan hubungan yang berbanding lurus, artinya sema-kin tinggi nilai X maka semakin besar pula nilai Y.

Tubuh serangga yang terinfeksi dan mati, bisanya akan mengalami

\section{SIMPULAN}

Mortalitas imago D. citri akibat infeksi $B$. bassiana sudah mulai terjadi pada hari kedua. Laju mortalitas kumulatif terendah D. citri sebesar $10 \%$ pada kerapatan konidia terendah yaitu $10^{3}$ konidia/ml, sedangkan laju kumulatif mortalitas tertinggi sebesar $53.33 \%$ pada kerapatan konidia tertinggi yaitu $10^{8}$ konidia/ml. Semakin tinggi kerapatan konidia/ml yang digunakan maka semakin tinggi mortalitas yang disebabkan.

\section{DAFTAR PUSTAKA}

Agustin D. 2014. Keefektifan cendawan entomopatogen Beauveria bassiana (Balsa-mo) Vuillemin dan Lecanicillium lecanii (Zimm.) Zare \& Gams terhadap peng-gerek batang jagung asia Ostrinia furnacalis Guenee (Lepidoptera: Crambidae) [tesis]. Bogor (ID): Institut Pertanian Bogor.

Ahdiaty I. 2013. Pengaruh umur cendawan Beauveria bassiana (Balsamo) Vuillemin mumifikasi dan terlihat diselimuti miselia cendawan. Imago D. citri yang telah mati yang terinfeksi $B$. bassinaterlihat diselimuti miselia berwarna putih. Menurut laporan Jaurhalina (1999) hifa muncul menembus inte-gumen yang paling lunak, yaitu diantara ruas-ruas tubuh serangga dan alat mulutnya. Berdasarkan hasil penelitian juga diketahui bahwa tidak semua bangkai imago D. citriyang terinfeksi cendawan akan muncul miselia keluar dari tubuhnya. Hal ini terjadi karena kondisi lingkungan yang kurang sesuai untuk perkem-bangan miselia cendawan di luar tubuh inangnya (Trizelia 2005).

terhadap infektifitasnya pada Cylas formicarius Fabricius (Coleoptera: Brenti-dae) [skripsi]. Bogor (ID): Fakultas Pertanian, Institut Pertanian Bogor.

Besheli BA, Khambay B, Cameron S, Deadman ML, Butt TM. 20oo. Inter and intraspesific variation in destruxin production by insect pathogenesis Metarhizium spp., and its significance to pathogenesis. J of The Myco-phatology. 104: 447-452.

Bove JM. 2006. Huanglongbing: A Destructive, Newly-emerging, Century-old Disease of Citrus. J of Plant Pathology 88: 7-37.

Dwiastuti ME, Nawir W, Wurtantini. 2007. Uji patogenisitas jamur entomopatogen Hirsutella citriformis, Beauveria bassiana, dan Metarhizium anisopliae seca-ra eka dan dwiinfeksi untuk mengendalikan Diaphorina citri Kuwayama. J Hort. 17 (1): 75-8o.

Ferron P. 1985. Fungal Control. Comprehensive Insect Phisiology.Biochem Pharmacol. 12: 313-346.

Gao Y, Reitz SR, Wang J, Xu X, Lei Z. 2012. Potential of a strain of the entomopathogenic fungus Beauveria bassiana (Hypocreales: Cordycipitaceae) as a biological control agent against western flower thrips, 
Frankliniella occidentalis (Thysanoptera: Thripidae). Biocontrol Science and Technology. 22(4): 491-495.

Goettel MS, Inglis GD. 1997. Manual of techniques in insect pathology: Hypomycetes. Lacey LA, editor. California (US): Academic Pr.

Himawati MK. 2003. Toksisitas Metoksifenosida terhadap Helicoverpa armigera.Agrosains 5: 1.

Jaurhalina. 1999. Potensi Beauveria bassiana sebagai cendawan entomopatogen pada hama ulat grayak (Spodoptera litura). Agrista. 3(1): 64-67.

Ratnawati, Kardhinata, E.H., Sartini, 2016, Identifikasi dan Penentuan Jenis Cendawan yang Menginfeksi Kulit Pasien Balita di Rumah Sakit Umum Pusat Haji Adam Malik Medan, BioLink, Vol. 2 (2), Hal :90-99

Klinger E. 2003. Susceptibility of adult colorado potato beetle (Leptinotarsa decemlineata) to the fungal entomopathogen Beauveria bassiana [tesis]. Maine (US): University of Maine.

Pacheco FLG, Wong LJG, Arroyo JIL, Guerra RR, Zapata IQ.2013.Optimization of pathogenicity tests for selection of native isolates of entomopathogenic fungi isolated from citrusgrowing areas of México on adults of Diaphorina citri Kuwayama (Hemiptera: Liviidae). Florida Entomologist 96 (1): 187-195.

Prayogo Y, Suharsono. 2005. Optimalisasi pengendalian hama penghisap polong kedelai (Riptortus linearis) dengan cendawan entomopatogen Verticillium lecanii. J Litbang Pertanian. 24(4).

Prijono D. 1985. Penuntun Praktikum Pestisida dan Alat Aplikasi Bagian Insektisida. Bogor: IPB

Rai D, Updhyay V, Mehra P, Rana M, Pandey AK. 2014. Potential of entomopathogenic fungi as biopesticides. Ind $J$ Sci Res and Tech. 2(5):7-13.

Steinhaus EA. 1999. The Effects of Diseases of Insect Populations. Hilgardia. 23 (9):97261.

Strack BH. 2003. Biological control of termites by the fungal entomopathogen Metarhizium anisopliae [Internet].[diunduh pada 2015 Agus17] Tersedia pada: http://www.utoronto.ca/forest/termite/ metani 1.htm
Surtikanti, Yasin M, Tandiabang J. 2011. Pengendalian hama kumbang bubuk menggunakan cendawan Beauveria bassiana Vuill. berupa tepung. Prosiding Seminar Nasional Serealia 2011; Maros. Maros (ID): Balai Penelitian Tanaman Serealia.

Surtikanti, Yasin M. 2009. Keefektifan entomopatogenik Beauveria bassiana Vuill. dari berbagai media tumbuh terhadap Spodoptera litura F. (Lepidoptera : Noc-tuidae) di laboratorium; 2009; Maros. Maros (ID): Balai Penelitian Tanaman Serealia.

Trizelia. 2005. Cendawan entomopatogen Beauveria bassiana (Bals.) Vuill. (Deutero-mycotina: Hypomycetes): keragaman genetik, karakterisasi fisiologi dan viru-lensinya terhadap Crocidolomia pavonana (F.) (Lepidoptera: Pyralidae) [disertasi] Bogor (ID): Institut Pertanian Bogor.

Vey A, Hoagland RE, Butt TM. 2001. Toxic metabolites of fungal biocontrol agent. Di dalam: Fungi as biocontrol agent, progress, problem, and potential. Butt. 
BioLink, Vol. 4 (1) Agustus 2017: hal. 82-89 